\title{
BANGKOK: \\ THE SINKING METROPOLIS
}

by

Prinya Nutalaya and Jon L. Rau

\begin{abstract}
Bangkok is located on a flat deltaic-marine plain 0.5 to $1.5 \mathrm{~m}$ above mean sea level. In the past two decades increased pumping of groundwater within the metropolitan area has led to the reduction of pore pressures, compression of soils and surficial deposits, drastic lowering of piezometric levels, and ground settlements of more than $0.5 \mathrm{~m}$, with a maximum annual rate of $10 \mathrm{~cm}$ in some parts of the city. This paper describes the Quaternary geological history and deposits of the Bangkok region, discusses the results of a major interdisciplinary study by Thai geoscientists and engineers on the causes and effects of subsidence, and looks at prospects for the future.
\end{abstract}

\section{Introduction}

Bangkok, with a present population of 5 million which is expected to increase to 6.5 million by 1992 , is the urban heart of central Thailand. It is situated on the Chao Phraya River $25 \mathrm{~km}$ north of the Gulf of Thailand. The city is closely associated with the highly respected Chakri Dynasty which founded Bangkok only 200 years ago, and whose modern representative, King Bhumiphol is regarded by many as the key to the long-term political stability of the region. The country faces new and pressing challenges. Hundreds of thousands of refugees on its eastern border and soaring inflation have placed an enormous financial burden on the people of Thailand, and this problem is felt most acutely in Bangkok.

Once known as "The Venice of the East", Bangkok is laced by dozens of large canals (klongs) which drain to the Chao Phraya River. The water table is at or near the surface throughout the city. Consequently, heavy monsoon rains, falling between May and October, quickly flood major parts of the urban area.

Over $30 \%$ of the water consumption in the metropolitan area is extracted from aquifers beneath the city. In 1979, groundwater use exceeded 1 million $\mathrm{m}^{3}$, per day from more than 11000 wells. In the main aquifers, pumping has resulted in a lowering of the piezometric level from its original position near the surface to more than $46 \mathrm{~m}$ below the ground. Widespread land subsidence is taking place throughout the metropolitan area east of the Chao Phraya River because of this excessive groundwater exploitation.

Bangkok is currently sinking at an average rate of $2-6 \mathrm{~cm}$ per year and in 23 years has subsided a maximum of $80 \mathrm{~cm}$ in some areas - more than 14 times the rate of subsidence in Venice, which sank $11 \mathrm{~cm}$ in 43 years but has stabilized in recent years (Berghinz, 1971). Bangkok's subsidence is now so serious that parts of the city are below sea level. Land subsidence has created a bowl-shaped depression in the southeastern metropolitan area, and flood waters reside there for longer periods now that the natural and man-made drainage is less efficient because of the reduced gradients in canals and storm drains.

The first studies of land subsidence in Bangkok took place in the late 1960s and early 1970s (Cox, 1968; Paveenchana, 1970; Brand and Paveenchana, 1971; Brand and Arbhabhirama, 1973; Brand, 1974; Brand and Balasubramaniam, 1976). Recently, an extensive study involving field instrumentation at 27 stations has been carried out by the Division of Geotechnical and Transportation Engineering of the Asian Institute of Technology (AIT, 1981; Nutalaya and Premchitt, 1981). The results have been integrated with an investigation by the Royal Thai Survey Department of the movement of surface benchmarks in Bangkok and with con- current studies of groundwater by the Division of Water Resources Engineering at AIT in cooperation with Thailand's Department of Mineral Resources.

The objectives of the ongoing AIT study are to determine the extent and rate of settling, the effect of pumping on the magnitude and rate of sinking, and measures that should be taken to prevent subsidence and to alleviate the problems of structural damage, prolonged flooding, and the development of topographic lows resulting from land subsidence.

\section{Geomorphology}

Bangkok occupies an area of about $303 \mathrm{~km}^{2}$ near the southern margin of a low-lying, flat, marine plain termed the Lower Central Plain (Fig. 1). The Upper Central Plain begins where

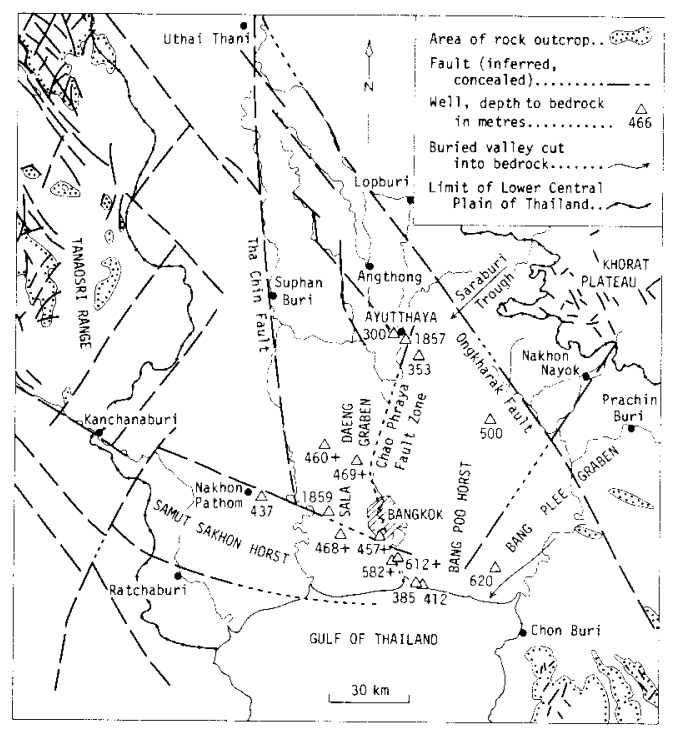

Figure 1: Structural framework of the Lower Central Plain of Thailand.

four rivers, the Ping, Wang, Yom, and Nan, rising in northern Thailand, combine to form the Chao Phraya River at Nakhon Sawan, $220 \mathrm{~km}$ north of Bangkok. A fifth tributary, the $\mathrm{Pa}$ Sak, draining borderlands on the nor theast side of the Central Plain, enters the Chao Phraya River at Ayutthaya. By the time the river reaches Ayut thaya it flows on a surface that is essentially flat, dropping only another $2.5 \mathrm{~m}$ over the $100 \mathrm{~km}$ to Bangkok. The sedimentary fill of the Chao Phraya Basin is truncated by a peneplain which has been entrenched by the Chao Phraya River between Nakhon Sawan and Ayut thaya. 
The modern Chao Phraya has developed a meander belt about $10 \mathrm{~km}$ wide down the centre of the Lower Central Plain. Its levees are low and poorly defined and are not high enough to prevent widespread flooding of areas north of Bangkok, despite attempts made to control the monsoon flows and to use them for irrigation of floating rice on both sides of the river in the backswamp areas.

\section{Geology}

Block faulting in the Late Pliocene-Pleistocene dropped the Chao Phraya basement (a complex of granites, carbonates, flysch, turbidites and cherts) into a graben primarily defined by $\mathrm{N}-\mathrm{S}$ faults. Infilling of the graben began contemporaneously as the border faulting stepped the basement down toward the axial area of the basin (for a review of the regional geology see Rau and Nutalaya, in press).

After the block faulting, the region extending from Uthai Thani to the Gulf consisted of horsts and grabens with rhombohedral shapes forming discontinuous, narrow mountain ranges and intervening basins. Some of the faults remained active during the Pleistocene and Holocene and control the present drainage and the topography on the floor of the Gulf of Thailand.

As basin infilling continued throughout the Quaternary the fault-block mountains were buried by a sequence of clastic sediments consisting of alluvial sands and gravels interbedded with floodplain silts and clays grading seaward into deltaic clastics and marine clays. The basement topography has a relief of more than $1800 \mathrm{~m}$ between poorly consolidated Quaternary sediments and the much more consolidated rocks of Paleozoic and Mesozoic age constituting the floor of the Chao Phraya Basin.
Following the Pliocene uplift and Pleistocene infilling, the development of alluvial fans and pediments occurred around the edge of the basin. Finally, the sea invaded the Bight of Bangkok and transgressed over the Central Plain beyond Uthai Thani in the Late (?) Pleistocene, receding during the period from about 45000 to 14000 years ago, and making its last transgression over the Central Plain as far as Ayut thaya from 11000 to 3000 years ago.

It is interesting to note that five major cities of the Lower Central Plain are located either on or near the beach which defines the edge of the Bangkok embayment (Fig. 2). These cities, Ratchaburi, Nakhon Pathom, Ayutthaya, Nakhon Nayok and Prachin Buri, at one time may have been ports on the edge of the Bangkok embayment. During the past 3000 years the sea has retreated from the plain, leaving behind a veneer of soft marine clay that now mantles $13800 \mathrm{~km}^{2}$ of the Lower Central Plain to an average depth of $15 \mathrm{~m}$ (Fig. 2).

This unit, the Bangkok Clay, is the most important one in the stratigraphic sequence from the point of view of land subsidence in the Bangkok area. The soft clay is found at altitudes from $0.5-2 \mathrm{~m}$ above sea level and accounts for $40 \%$ of the compression that has occurred in Bangkok due to groundwater exploitation. Beneath the Bangkok Clay, the Thai Department of Mineral Resources has identified nine aquifers within the upper $550 \mathrm{~m}$ of sediments (Fig. 3). These aquifers consist primarily of sand and gravel separated by clay. Where the clay layers are absent, however, direct hydraulic connection exists between adjacent aquifers.

\section{Flooding}

Flooding is related to heavy periods of monsoon rain, but floods such as occurred in October, 1942, which caused

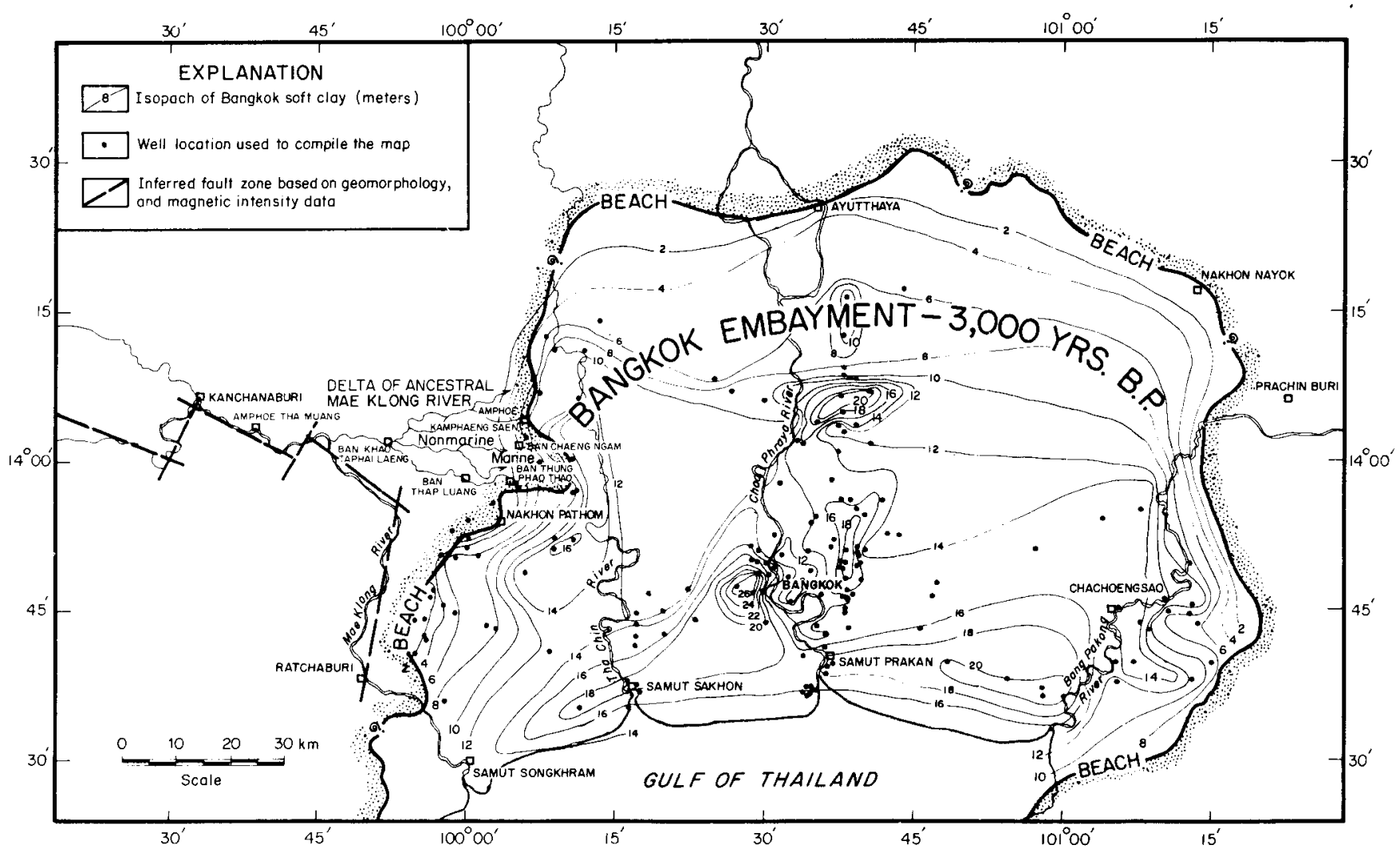

Figure 2: Isopach map of the Bangkok Clay, showing the Holocene Bangkok Embayment. 

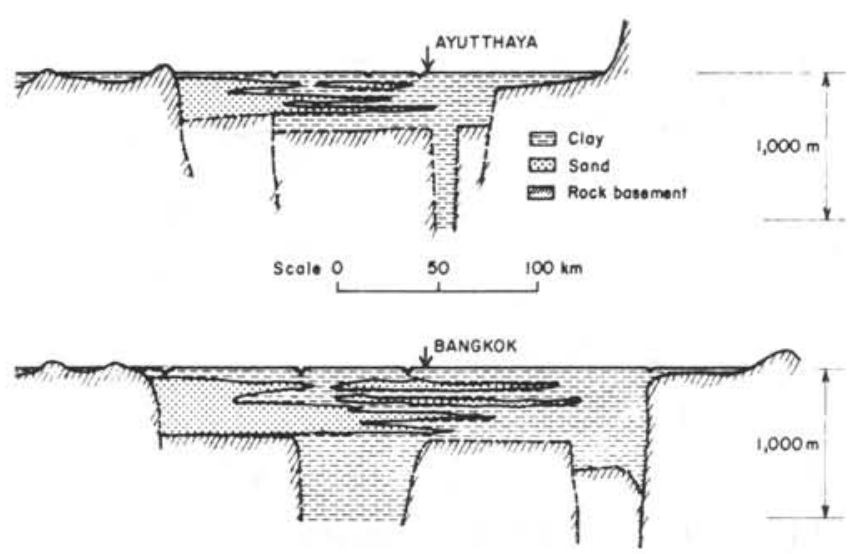

Figure 3: Schematic E-W cross-sections of the Lower Central Plains of Thailand.

several hundred millions of dollars damage, no longer threaten the city. Since then, the construction of the Chao Phraya Dam, on the main stem of the Chao Phraya River (built in 1957) and the Bhumiphol Dam on the Ping (1964), have reduced the threat of catastrophic floods in Bangkok. Nevertheless, in the period since 1964 the frequency of moderate flooding has increased causing health hazards, disruptions to traffic and communication systems, and damage to buildings and roads. The cost of flood control has been a heavy burden for the city.

The present drainage system within the city is operating at a gradient of 1:60 000, the Chao Phraya falling only $25 \mathrm{~cm}$ in its $15.5 \mathrm{~km}$ course through the city. Monsoon rains rapidly flood the city because of the inability of the drainage system to function efficiently. Should heavy rains correspond with high tides and strong onshore winds, the drainage system cannot discharge the water that accumulates on city streets. Major thoroughfares are quickly flooded and traffic within the city is paralyzed. The water runs over curbs and floods downtown shops and buildings. Within hours, rains may flood some of the main streets to a depth of more than $0.5 \mathrm{~m}$.

The Chao Phraya can discharge $1500 \mathrm{~m}^{3} / \mathrm{sec}$ below the city without flooding low-lying areas but, during the monsoon season, $2000-2500 \mathrm{~m}^{3} / \mathrm{sec}$ of water enter the city from the vast plain above. The drainage from the klong system is controlled by the height of the Chao Phraya River and the tide level. Because gradients within the city are nearly horizontal, it is only the gates at the mouth of the major canals that prevent the river from backing up into the canal network during high tides. During the flood season the city attempts to control urban runoff by employing a vast system of portable pumps which gradually move the water from one drain or canal to another. Eventually, the water is pumped over the natural levees into the Chao Phraya River.

Subsidence has made the drainage problem more acute. The klongs have become so sluggish that discharge of their effluent-laden waters to the Chao Phraya takes much longer than normal. They are the recipients of residential sewage, street and kitchen wastes and innumerable discharges from thousands of shops and small businesses as well as from the more than one-quarter million unauthorized settlements that line them. It has been estimated that a total of 1 million $\mathrm{m}^{3}$ of polluted water is produced in Bangkok each day (Maxwell, 1973). This is equivalent to the total amount of groundwater pumped from underground storage in sand and gravel aquifers in Bangkok each day. It is only a matter of time before some of them will be unable to flow into the Chao Phraya River.
A 30-year project is under way to protect Bangkok from floods by the installation of a sewage system, aqueducts, the deepening of canals, and the elevation of existing roads. Drainage tunnels $3.3 \mathrm{~m}$ in diameter and many kilometres long are being constructed. These storm sewers lie at a depth of 4 $\mathrm{m}$ and grade to $7.5 \mathrm{~m}$ at their lower ends near the great bend of the Chao Phraya River. There, pumping stations will lift the water $9.5 \mathrm{~m}$ and discharge up to $16 \mathrm{~m}^{3} / \mathrm{sec}$ into the river. The new drainage scheme will cost more than $\$ 100$ million

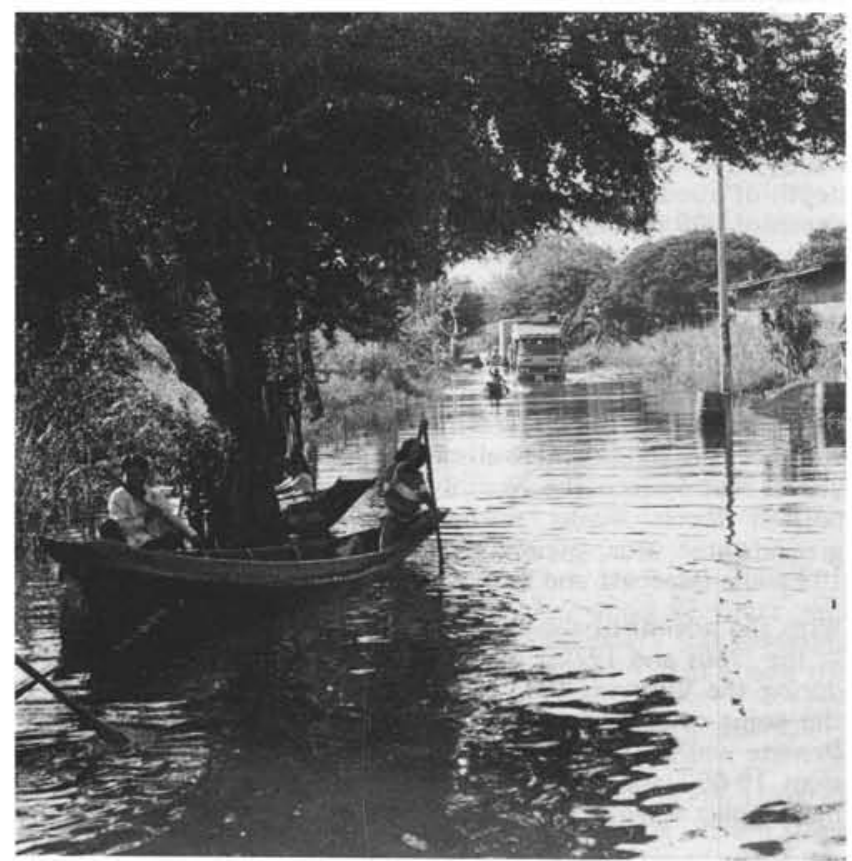

A suburban road in Bangkok at the height of the monsoon season.

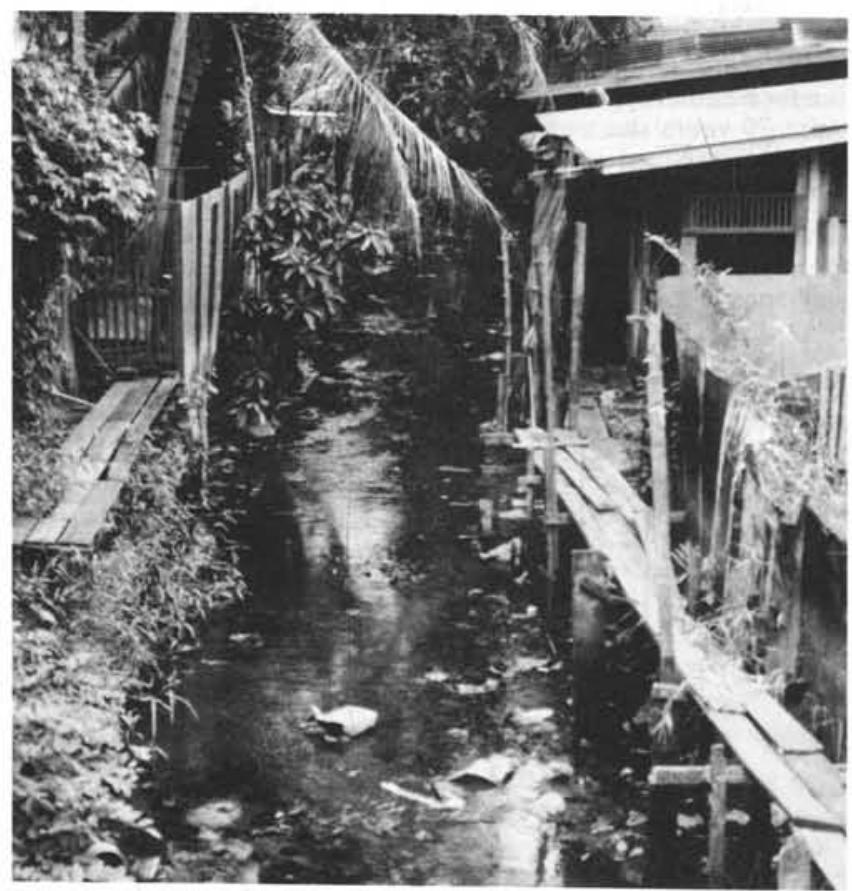

In many parts of the city the klongs are black, fetid and smelly. 
(U.S.), and will drain a $400 \mathrm{~km}^{2}$ area. The rapid rate of settlement, however, makes it difficult to plan and install a system when benchmarks are subsiding $2-14 \mathrm{~cm} /$ year. Any design will be soon obsolete because of changing gradients in the sewage and natural drainage networks. Moreover, the subsidence issue is not taken seriously by the majority of Thai people who have long been accustomed to flooding. Groundwater pumping is uncontrolled at the present time.

\section{Groundwater Exploitation}

Groundwater has been used for over 60 years in the Bangkok area. The first $200 \mathrm{~m}$ of section below the surface contains more than a dozen individual sand and gravel lenses. Most of the groundwater is derived from the Nakhon Luang aquifer, which consists of several interconnected sand bodies at a depth of about $150 \mathrm{~m}$. A deeper aquifer, the Nontaburi, at a depth of $200 \mathrm{~m}$, has been increasingly exploited. In the upper $10 \mathrm{~m}$ of the Bangkok Clay, the annual change in groundwater level ranges from $1-2 \mathrm{~m}$ as a result of seasonal variations in rainfall. This is not affected by pumping from the deeper aquifers.

The first municipal well was drilled in 1953; more than 122 deep production wells were installed between 1956 and 1958 . Another 100 municipal wells have been drilled in the past 20 years, mainly into the Nontaburi sands. In 1963 the Metropolitan Water Works Authority (MWWA) was the largest groundwater user, pumping more than $350000 \mathrm{~m}^{3} /$ day from 138 wells (Metcalf and Eddy, 1977).

With the advent of the construction boom and industrial surge in the 1960s and 1970s, probably related to the capital influx during the Vietnam War, groundwater extraction expanded to the point where city wells now yield from $660-9600 \mathrm{~m}^{3} /$ day. Private wells with yields from $50-9600 \mathrm{~m}^{3} /$ day number more than 10000 and supply a variety of users: homes, hotels, many government offices, hospitals, and schools.

As a result of the increasing exploitation of groundwater, piezometric levels have rapidly declined and salinity has increased. Before the recent heavy industrial development and urban expansion, the groundwater level associated with the aquifers was within $1 \mathrm{~m}$ of ground surface, while a few wells were actually free-flowing. By 1959 the piezometric surface had dropped to about $9 \mathrm{~m}$ below the surface. For the next 20 years the water level in wells screened in the shallow aquifers dropped at a rate of 2 to $3 \mathrm{~m}$ per year, and and is now more than $45 \mathrm{~m}$ below the surface.

This decline in the piezometric surface has lowered the pore pressure in the the Bangkok Clay adjacent to the developed horizons (Fig. 4). Shallow aquifers have been dewatered and

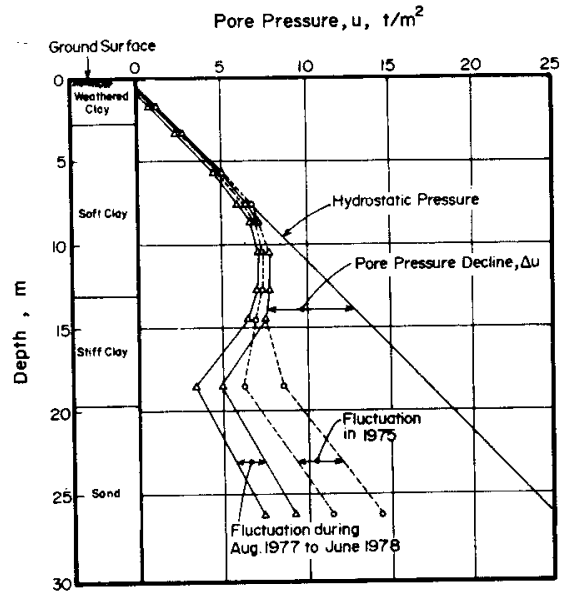

Figure 4: Pore pressure decline with depth at Chulalongkorn University.

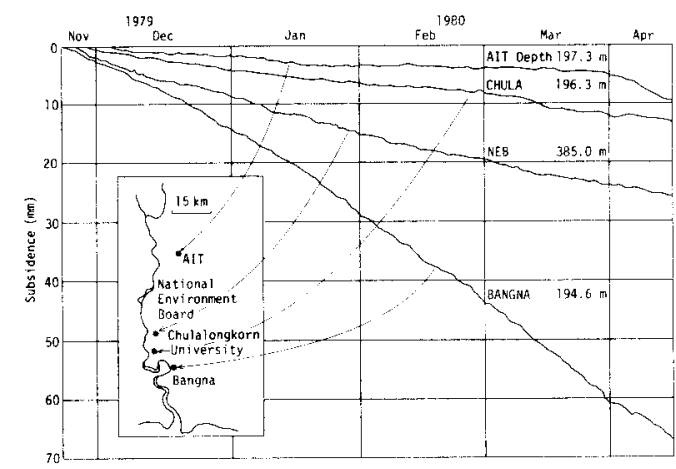

Figure 5: Record of continuous subsidence at four locations.

connate water induced from the marine clays sandwiched between the sands in the upper $50 \mathrm{~m}$ of the section. The groundwater extracted is thus becoming more saline, with chloride levels in some areas now ranging from 500-7 000 parts per million. A large number of wells have had to be abandoned.

\section{Field Measurements}

In the AIT study, compression indicators and piezometers were installed at 27 stations throughout Bangkok. These stations constitute a monitoring network which provides information necessary for the interpretation of the cause of the settlement and for the prediction of the future rate and extent of subsidence.

The continuous records of surface subsidence at four stations are shown in Figure 5. It is obvious that compression at Bangna, where heavy pumping takes place, is much greater than that at the AIT campus, $42 \mathrm{~km}$ north of Bangkok. The results obtained agree with those from first-order levelling which show rapid subsidence of about $10 \mathrm{~cm} / \mathrm{yr}$ in the $\mathrm{SE}$ part of Bangkok and very little sinking north of the city limits (Fig. 6). Every six months the Royal Thai Survey Department

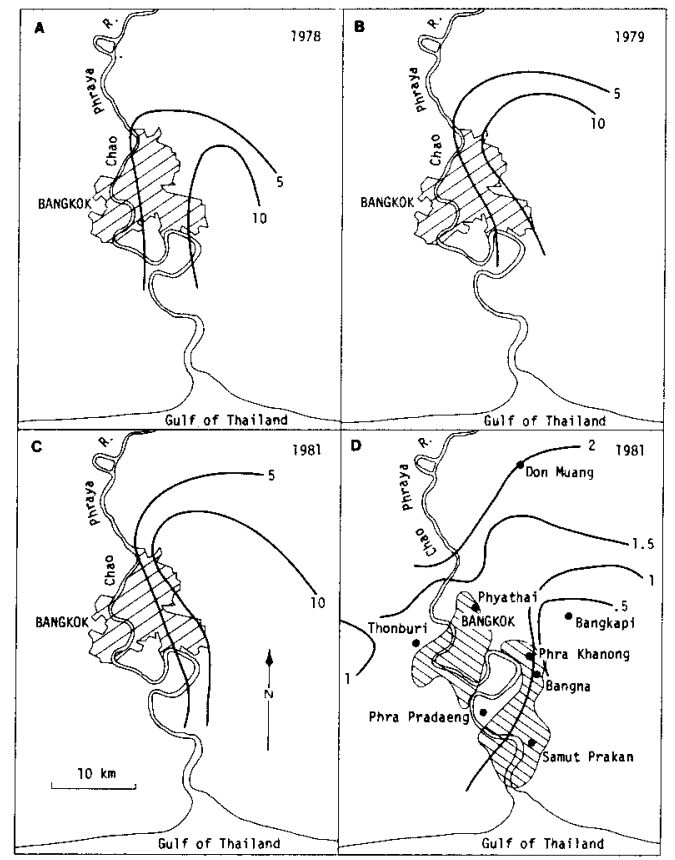

Figure 6: Contours of equal ground subsidence in $\mathrm{cm}$ per year $(A, B, C)$ and of ground surface elevation showing areas of moderate to high concentration of private wells $(D)$. 


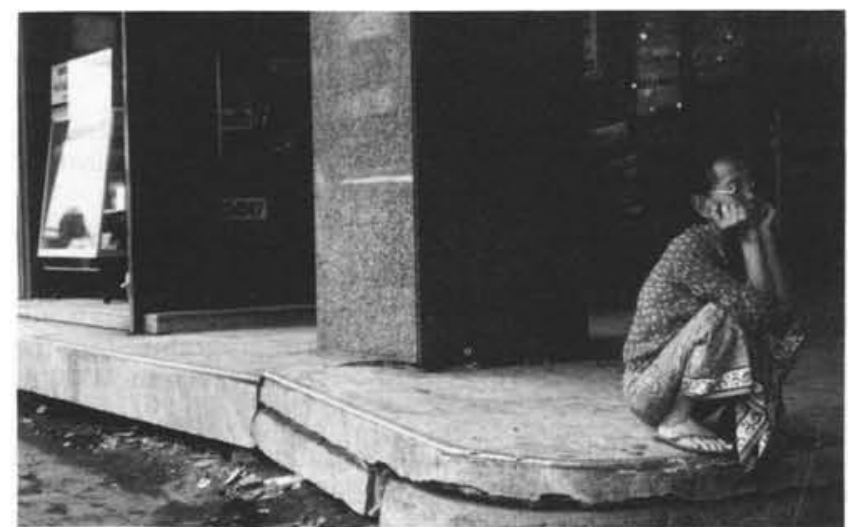

Streets and sidewalks subside but buildings set on deep piling remain stable.

carries out precise levelling from mean sea level to surface reference points. More than six runs have been made during the past three and one-half years. Based on these levelling results it has been found that the existing benchmarks in Bangkok are $30-80 \mathrm{~cm}$ lower than the original elevations surveyed $30-40$ years ago.

The results from the observation of deep compression indicators confirmed the rate of surface subsidence obtained from the results of the levelling surveys. The Bangkok Clay contributes $40 \%$ of the total subsidence, and $40-55 \%$ can be attributed to strata between the base of the Bangkok Clay and the depth of $200 \mathrm{~m}$. Only $5-15 \%$ of the compression occurs below a depth of $200 \mathrm{~m}$.

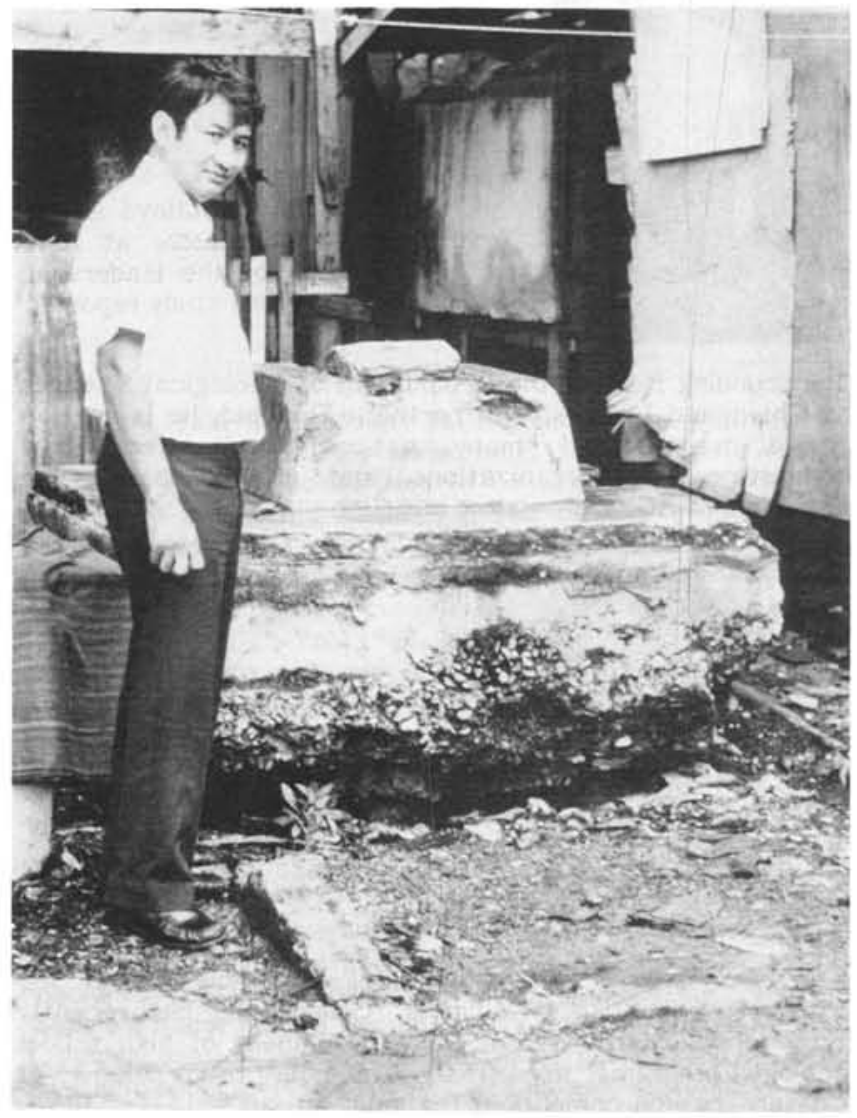

Well-head protrusion in Lumpini Park, central Bangkok. 60 $\mathrm{cm}$ in 14 years.

\section{Structural Damage from Subsidence}

Structures on deep piling driven to the firm sand layers below the Bangkok Clay are stable because compression is negligible in the sand horizons. Bridge approaches commonly subside, but the mid-section of the bridge remains firmly supported on deep piling. Subsidence causes buildings founded on deep piling to "stand up" above the sinking surface. The most obvious evidence of sinking is seen in many parts of the Bangkok business district along Rama I, Phloen Chit and Sukhumvit Roads. The results are cracked sidewalks and scarps which may run the entire length of a building parallel to its foundation.

One cosmetic solution to this problem has been to periodically add a step to the stairs leading into these buildings. More or less constant repair of the sidewalks and steps is required to prevent the development of an unsightly gap at the place where the sidewalk would normally meet the steps or foundation of the building.

Groundwater development is also affected by sinking because it causes damage to well casings and water transmission pipes. Almost all wells in the Bangkok area protrude above ground surface (AIT, 1978). The observed protrusions of wellheads are larger for those wells which have been in service for a long time, and this is especially obvious in wells that were installed 20 to 30 years ago. Two wells in downtown Bangkok have casings which protrude 50 and $40 \mathrm{~cm}$ respectively, suggesting that subsidence there has been about one-half meter since their installation 26 and 22 years ago. A well $140 \mathrm{~m}$ deep at Chulalongkorn University was installed 19 years ago, and today its casing protrudes $35 \mathrm{~cm}$ above the adjacent ground surface.

\section{The Future}

Prior to the beginning of the current study, predictions of land subsidence in the Bangkok area were made on the basis of the compression characteristics of subsoils and measurements of the decline in groundwater levels. Brand and Balasubramaniam (1976) forecast a probable ultimate subsidence of about $2.0-3.1 \mathrm{~m}$ on the assumption that the residual pore pressures in the uppermost $600 \mathrm{~m}$ of the Bangkok section would be fully dissipated as a result of a groundwater level decline from 10-40 m. Premchitt (1978) used a mathematical model to predict an annual rate of surface subsidence ranging from 1.2-7.2 cm/year, with a total settlement of $1.4-2.1 \mathrm{~m}$ by 1995. These studies have predicted results which are close to those observed from field measurements in this investigation (Fig. 7),

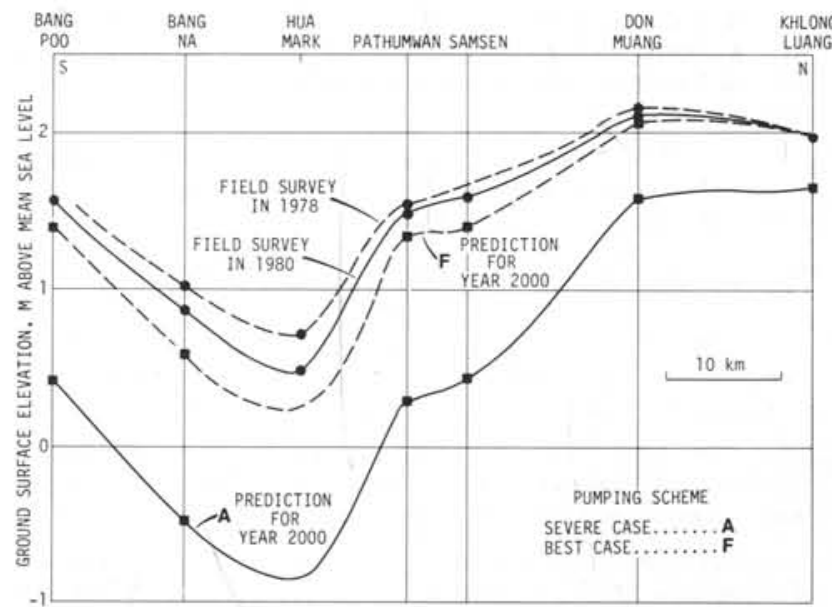

Figure 7: Profiles of ground surface elevation through Bangkok from 1978 and 1980 field surveys and from model predictions to 2000 . 
At present there is no comprehensive plan to solve the subsidence problem in Bangkok. However, the MWWA master plan if duly executed will provide a distribution system that will bring enough surface water to alleviate groundwater pumping in the critical areas of Bang Kapi, Phra Kanong and parts of Phra Pradaeng. If groundwater pumping is strictly controlled or phased out in these areas, the mathematical model predicts considerable recovery in the groundwater level and by 1990 subsidence may be halted. Artificial recharge may accelerate the recovery of groundwater levels, and further studies in this direction are now under way at AIT.

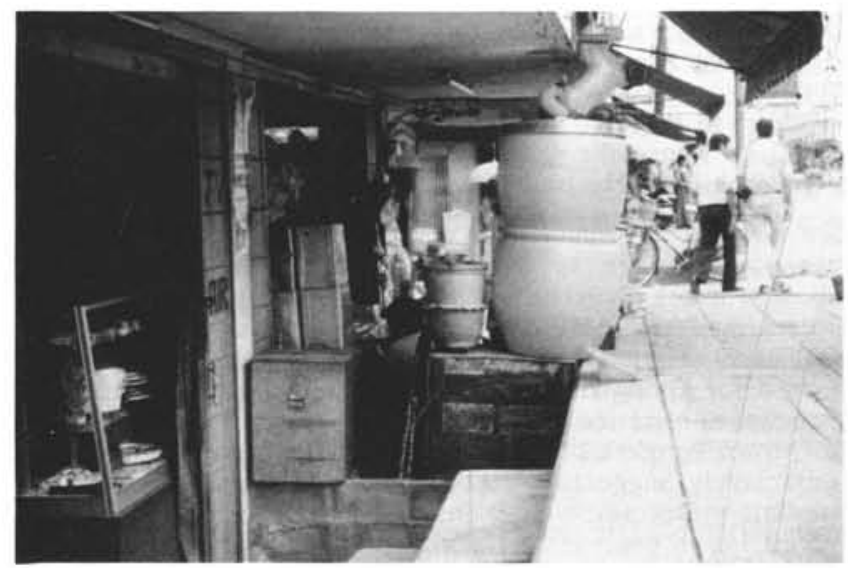

In Thonburi where subsidence has been especially marked, shops have had to be closed because their ceilings are now too close to sidewalk levels. Here the roads and sidewalks have been built up, layer by layer, in order to keep thoroughfares clear of floods.

\section{Acknowledgements}

The authors would like to thank E.W. Brand who initiated this investigation and their colleagues A.S. Balasubramaniam, R.P. Brenner, J. Premchitt, and T. Akagi. Prof. John Hugh Jones of AIT is thanked for the many courtesies shown J.L. Rau during his three summers in Bangkok. The investigation of land subsidence in Bangkok was made possible by a research grant from the National Environment Board of Thailand.

\section{References}

AIT, 1981, Investigation of land subsidence caused by deep well pumping in the Bangkok area: Asian Inst. of Tech., Div. of Geotech. and Trans. Eng., Report 1978-1981, Bangkok, $353 \mathrm{p}$.

Akagi, T., 1979, Some land subsidence experiences in Japan and their relevance to subsidence in Bangkok, Thailand: Geotech. Eng., v. 10, p. 1-48.

Berghinz, C., 1971, Venice is sinking into the sea: Civil Eng., v. 41 , p. $67-71$.

Brand, E.W., 1974, Predictions of subsidence in the city of Bangkok: Proc. 2nd. Int. Conf. Eng. Geol., Sao Paulo, v. 1, p. III21.1-III21.10

Brand, E.W. and Arbhabhirama, A., 1973, The groundwater resources of Bangkok: Proc. Int. Symp. Dev. of Groundwater Res., Madras, v. 3, p. V43-V51.

Brand, E.W. and Balasubramanian, A.S., 1976, Soil compressibility and land subsidence in Bangkok: Proc. 2nd Int. Symp. Land Subsidence, Anaheim, California, IAHS Pub. No. 121 , p. 365-374.
Brand, E.W. and Paveenchana, T., 1971, Deep-well pumping and subsidence in the Bangkok area: Proc. 4th Asian Reg. Conf. Soil Mech. Found. Eng., Bangkok, v. 1, p. 1-7.

Cox, J.B., 1968, A review of the engineering characteristics of the recent marine clays in southeast Asia: Asian Inst. of Tech. Res. Report 6, Bangkok.

Maxwell, J.F., 1973, Water pollution: the nature of the problem: Business in Thailand, Aug. 1973.

Metcalf and Eddy Inc., 1977, Report on groundwater monitoring, well construction and future programs for the Metropolitan Water Works Authority: Report to MWWA, Bangkok.

Nutalaya, P. and Premchitt, J., 1981, Investigation of land subsidence in Bangkok area, Thailand: Bull. Liaison Lab. des Ponts et Chausées, Special X, p. 63-70.

Paveenchana, T., 1970, The effect of deep well pumping on land subsidence in the Bangkok area: M. Eng. Thesis, Asian Inst. of Tech., Bangkok.

Premchitt, J., 1978, Analysis and simulation of land subsidence with special reference to Bangkok: D. Eng. Thesis No. D37, Asian Inst. of Tech., Bangkok.

Rau, J.L. and Nutalaya, P., in press, Application of geomorphology to land subsidence in Bangkok, Thailand: Proc. 13th Ann. Binghampton Geomorphology Symp., Kent State Univ., Kent, Ohio.

\section{ABOUT THE AUTHORS:}

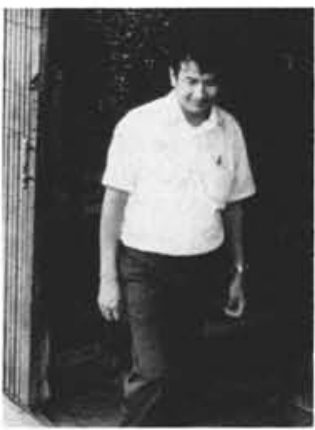

Dr. Prinya Nutalaya is Associate Professor at AIT, and one of the leaders of the Bangkok study reported above.

The founding Head of the Department of Geological Sciences at Chiengmai University in northern Thailand, he is now an active member of many national and international committees and organizations, and in his spare time President of AGID.

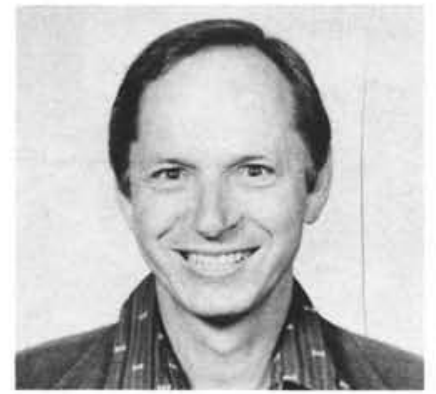

Dr. Jon. L. Rau is a former hydrogeologist with USGS and staff member of the Geology Department at Kent State University in Ohio.

Now Associate Professor of Geological Sciences at the University of British Columbia, Canada, he has recently turned his attention from the development of high school geology programs in British Columbia to problems of Quaternary environments in Thailand. 